\author{
Katarzyna PIETRUCHA-URBANIK ${ }^{1}$ \\ Aneta BERNACKA ${ }^{2}$
}

\title{
ANALYSIS OF WATER INFRASTRUCTURE DEVELOPMENT - A CASE STUDY OF THE EXEMPLARY WATER SUPPLY SYSTEM
}

\begin{abstract}
The paper presents the characteristics of the water supply infrastructure in Lubaczów. Thereafter the analysis of the water supply infrastructure based on the collected operational data was performed. Indicators characterizing the water supply infrastructure in the years 1995-2014 were determined. In the analysis the following parameters were used: length of water supply network, the number of water supply connections, water consumption. The analysis was based on data get from the Central Statistical Office for $1995 \div 2014$ [4]. The increase in the water supply network in Lubaczów in the considered period amounted 125,8\%, while the average increase in the length of water supply network was $0,3 \mathrm{~km} / \mathrm{year}$, per one inhabitant falls $1,87-2,38 \mathrm{~m}$ of the water supply network. The value of the load intensity of the water supply system in the Podkarpackie region in the years 1995-2009, as opposed to Lubaczów, showed an increasing trend. The length of the water supply system per unit area was $0,88 \mathrm{~km} / \mathrm{km}^{2}$ in 1995 and has grown to a value of 1,11 $\mathrm{km} / \mathrm{km}^{2}$ in 2014. The number of water supply connections leading to residential buildings and collective waterworks increased from 1299 in 1995 to 1903. In 2014, the increase amounted $146,5 \%$. The average number of water supply connections per $1 \mathrm{~km}$ of water supply network in the years $1995-2014$ was $65 \mathrm{no} / \mathrm{km}$, while the difference between the maximum and minimum was $21 \mathrm{no} / \mathrm{km}$, which shows a slight increase of this indicator.
\end{abstract}

Keywords: water supply infrastructure, water supply system development indicators, failure rate, water supply system

\section{Introduction}

Lubaczów is a city located in the south-eastern Poland, in the Podkarpackie province, in the district Lubaczów, in the Tarnogrodzki Plateau, at the mouth of the river Sołotwy to Lubaczówka, near the state border with Ukraine. Currently the city has 12 thousands residents, a population density of 490 people $/ \mathrm{km}^{2}$. The share of working age population for the city is about $65 \%$ of the total population.

${ }^{1}$ Aneta Bernacka, Politechnika Rzeszowska

2 Autor do korespondencji/corresponding author: Katarzyna Pietrucha-Urbanik, Politechnika Rzeszowska, al. Powstańców Warszawy 6, 35-959 Rzeszów, tel. 17 8651703, kpiet@prz.edu.pl 
The population under the age of 18 years is about $20-25 \%$ of the population, while $10-15 \%$ are people of working age.

Water supply pipeline and other components of water supply include [10]:

- backhaul network of water from wells to water treatment plants (WTP),

- backhaul network of treated water from WTP to expansion tanks,

- water supply network with connections,

- the intake of water supplying the Municipality of Lubaczów (the city of Lubaczów).

Lubaczów is supplied with water from the underground water intake by six active drilled wells numbered $S-1 a, S-2, S-5 a, S-6 a, S-7, S-8$, of total capacity $202 \mathrm{~m}^{3} / \mathrm{h}$.

The well S-3 was constructed in 1976, now, since 1993, it is excluded from the operation due to technical wear and is going to be eliminated. At present it serves as a piezometer.

The main potential sources of pollution of groundwater in the area of wells S-1a and S-2 are sewage and rainwater collectors. Due to the relatively small depth of the foundation, 1,5-2,5 $\mathrm{m}$ below ground level and the presence of the semi-works with a thickness of 6,5-7,0 m, defaulting on aquifer, the threat from them is potentially vital [10].

Capacity of wells is greater than the demand and therefore they operate alternately, resulting in less technical wear.

In the analysis the following data were used: the length of the water supply network, water supply network density indicator, the number of water supply connections leading to residential buildings and the collective waterworks, the number of water supply connections per $1 \mathrm{~km}$, the intensity of the network load. The analysis can be used to describe the operation of water supply systems $[1,5$, $6,12,14,15]$. Analysis of the water infrastructure state in the Lubaczów city was conducted for the years 1995-2014 on the basis of data provided by the Central Statistical Office.

\section{Analysis of the water supply system of the Lubaczów city}

\subsection{Increase of the water supply network lenght in Lubaczów}

In the Lubaczów city some private buildings are supplied with water from own wells. In dry periods (low level of underground water), users of private wells can use water from the network, because of decreasing water resources.

The increase in the water supply system length for the whole city in the period 1995-2014 amounted to $125,8 \%$ (Fig. 1). The sudden growth of this indicator in 1998 by $11,7 \%$ in relation to 1997 was the result of a significant extension of the network, due to the expansion of the city. 


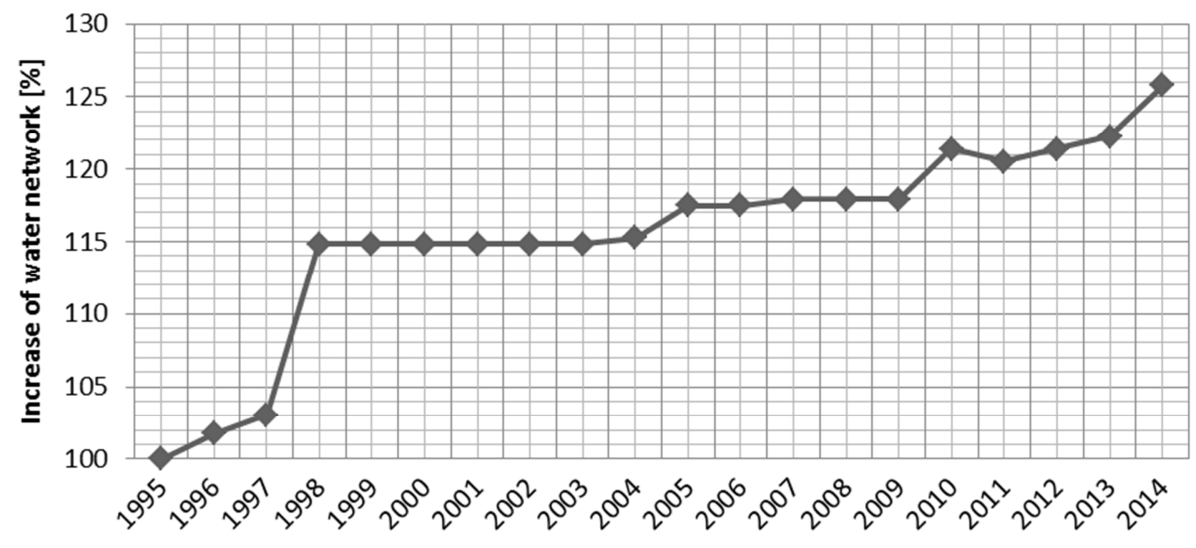

Fig. 1. Growth dynamics of the water supply system in Lubaczów

Rys. 1. Dynamika przyrostu sieci wodociągowej w Lubaczowie

The average increase in water length $p_{s r}$ can be determined according to the formula $[2,3]$ :

$$
\mathrm{p}_{\mathrm{sr}}=\left(\mathrm{l}_{2014^{-}} \mathrm{1}_{1995}\right) / \mathrm{t},[\mathrm{km} / \text { year }]
$$

where:

$1_{1995}-$ the length of the water supply system at the beginning of the observation period (in 1995), [km],

$1_{2014}$ - the length of the water supply system at the end of the observation period (in 2014), [km],

$\mathrm{t} \quad-$ observation time [years], $\mathrm{t}=20$ years.

On the basis of calculations the average increase of the length of the water supply network was $0,3 \mathrm{~km}$ per year. A small increase of the water network length in 1995-2014 was due to the lack of significant development of the city in terms of water supply systems construction and new residential buildings are located nearby the existing network. In 201267 houses were put into operation, what resulted in a significant expansion of the water supply network before the investment and final inspection.

\subsection{Indicators of equipment in water supply networks}

In 1995-1998 in Lubaczów fell about 1,9 m of water supply network per one inhabitant (Fig. 2) and in the years 1999 to 2013 the indicator increased from 2,1 to 2,23 m/inhabitant, reaching a value of 2,38 m/inhabitant in 2014 . Slight fluctuations in the length of the water supply system per one inhabitant can be seen. 


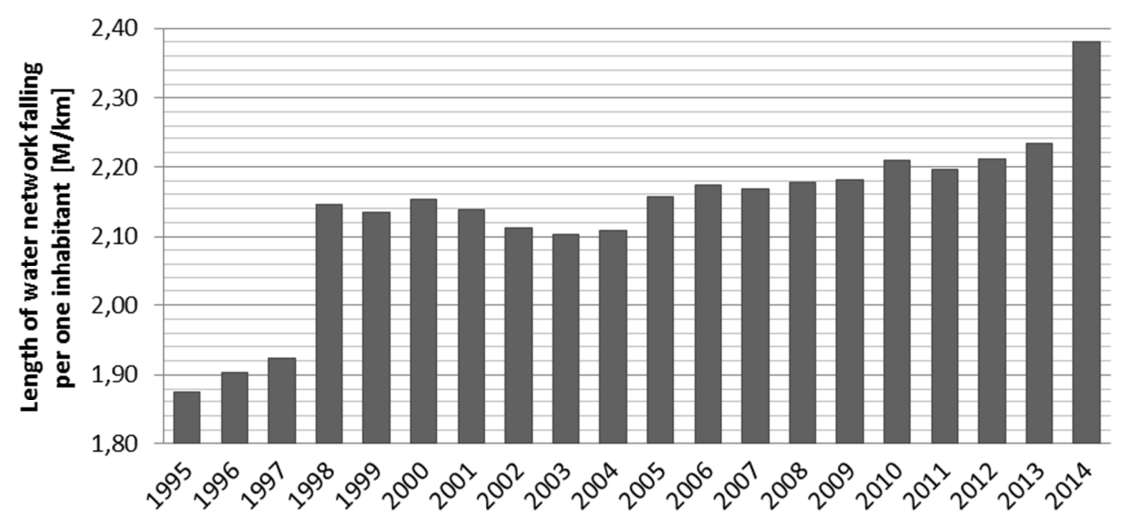

Fig. 2. Length of water network falling per one inhabitant of Lubaczów

Rys. 2. Długość sieci wodociągowej przypadająca na jednego mieszkańca Lubaczowa

The statistical analysis of unit length of water supply network per one inhabitant of Lubaczów was conducted for 20 years. The analysis showed that the average value of this indicator amounted to $2,13 \mathrm{~m} / \mathrm{inh}$ abitant. The range between the minimum and the maximum value in the $1995-2014$ was $0,51 \mathrm{~m} /$ inhabitant, reflecting the minimal development of the water supply system in the city.

Basic descriptive statistics for the water supply network length per one inhabitant of Lubaczów were as follows: average - 2,13, median - 2,16, minimum 1,87 , maximum -2.38 , the coefficient of variation $-55 \%$, the standard deviation - 0,12 , range $-0,51,10 \%$ percentile $-1,92,90 \%$ percentile $-2,21$.

Indicator, that shows the production capacity of water network and the degree of its use, is the intensity of the network loading qos calculated according to the formula $[2,3]$ :

$$
\mathrm{q}_{\mathrm{os}}=\mathrm{Q}_{\mathrm{d}} / \mathrm{L},\left[\mathrm{m}^{3} /(\mathrm{d} \cdot \mathrm{km})\right]
$$

where:

$\mathrm{Q}_{\mathrm{d}}$ - the average daily demand for water, $\left[\mathrm{m}^{3} / \mathrm{d}\right]$,

$\mathrm{L}$ - the length of the water supply network, $[\mathrm{km}]$.

The intensity of the water supply network use in Lubaczów in 2003-2014 was lower compared to previous years (Fig. 3). The highest intensity of network load was achieved in 2002 and amounted $77,1 \mathrm{~m}^{3} /(\mathrm{d} \cdot \mathrm{km})$ and the lowest $41,3 \mathrm{~m}^{3} /(\mathrm{d} \cdot \mathrm{km})$ in $2013-2014$. The main reason for this situation is the decrease of water consumption. The value of the intensity of the network loading in the Podkarpackie region in the years 1995-2009 showed an increasing trend ranged from $27,9 \mathrm{~m}^{3} /(\mathrm{d} \cdot \mathrm{km})$ in 1995 to $66,8 \mathrm{~m}^{3} /(\mathrm{d} \cdot \mathrm{km})$ in 2009 [11]. In Lubaczów, however, this indicator decreases over the years. The main reason for such situation is mainly low density of buildings and low water consumption. 


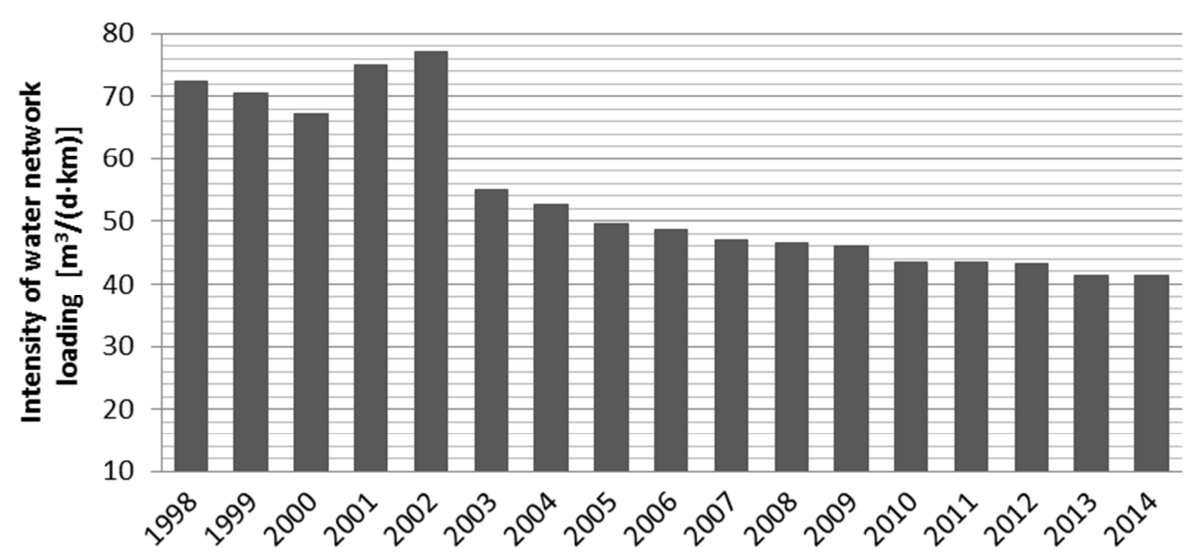

Fig. 3. Intensity of water network loading in Lubaczów

Rys. 3. Intensywność obciążenia sieci wodociągowej w Lubaczowie

A significant relationship between the ratio of the intensity of the water network loading and the number of inhabitants per $1 \mathrm{~km}$ of network in the period of 2003-2014 can be noticed (Fig. 4).

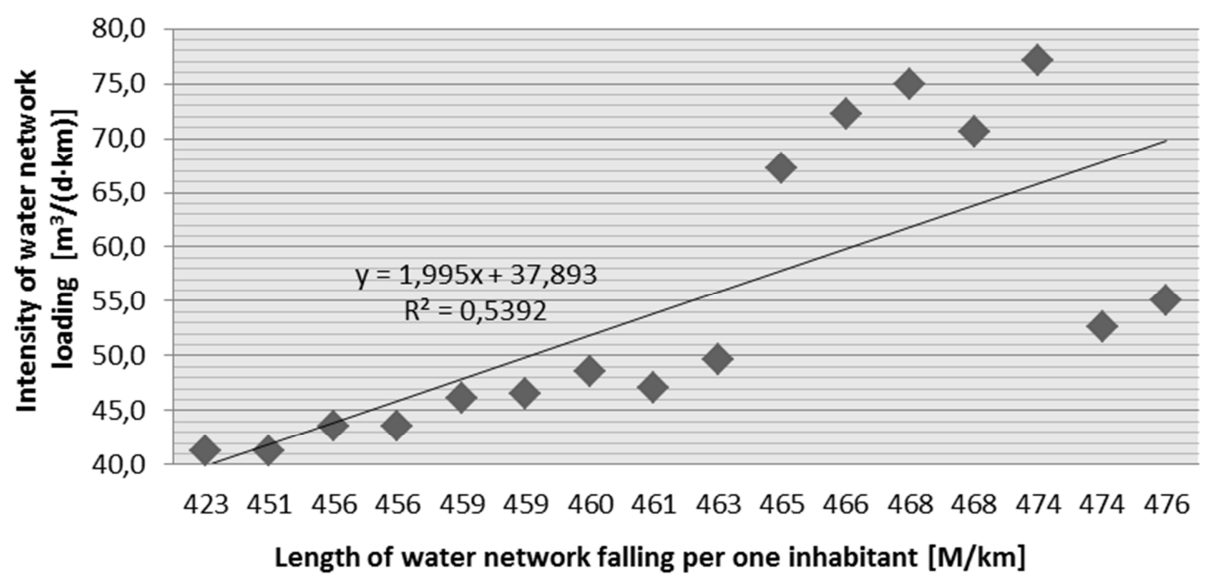

Fig. 4. The coefficients of the intensity of water network loading depending on the number of inhabitants of Lubaczów per $1 \mathrm{~km}$ of network

Rys. 4. Współczynniki intensywności obciążenia sieci wodociągowej w zależności od liczby mieszkańców Lubaczowa przypadających na $1 \mathrm{~km}$ sieci

Slightly less dependence indicate variables in 1998-2002, when the intensity of the water network loading in Lubaczów was much higher than in the following years. The coefficient of determination is 0,5392 , which indicates a strong relationship between the variables. 
Another indicator describing the water network state is the length of the water pipes per unit area of the city. In the years 1995-2014 the area of Lubaczów remained unchanged and equals $26 \mathrm{~km}^{2}$. In 1995 the density of the water supply system amounted to $0,88 \mathrm{~km} / \mathrm{km}^{2}$ and increased by $26 \%$ in 2014 to a value of $1,11 \mathrm{~km} / \mathrm{km}^{2}$. A sudden increase in the length of water supply network per $1 \mathrm{~km}^{2}$ of the city area in 1998 , of $12 \%$ compared to 1997 , was caused by the expansion of the water supply network.

Knowing the length of the water network, the number of water supply connections per $1 \mathrm{~km}$ of water supply network lśr can be determined according to the dependence $[2,3]$ :

$$
1_{\text {sr }}=\mathrm{n} / \sum 1_{\mathrm{r}},[\mathrm{no} / \mathrm{km}]
$$

where:

$\mathrm{n}$ - the number of water supply connections, [no],

$\sum 1_{\mathrm{r}}$ - the total length of the water network, [km].

The number of water supply connections in Lubaczów in the years 19952014 was shown in the Figure 5.

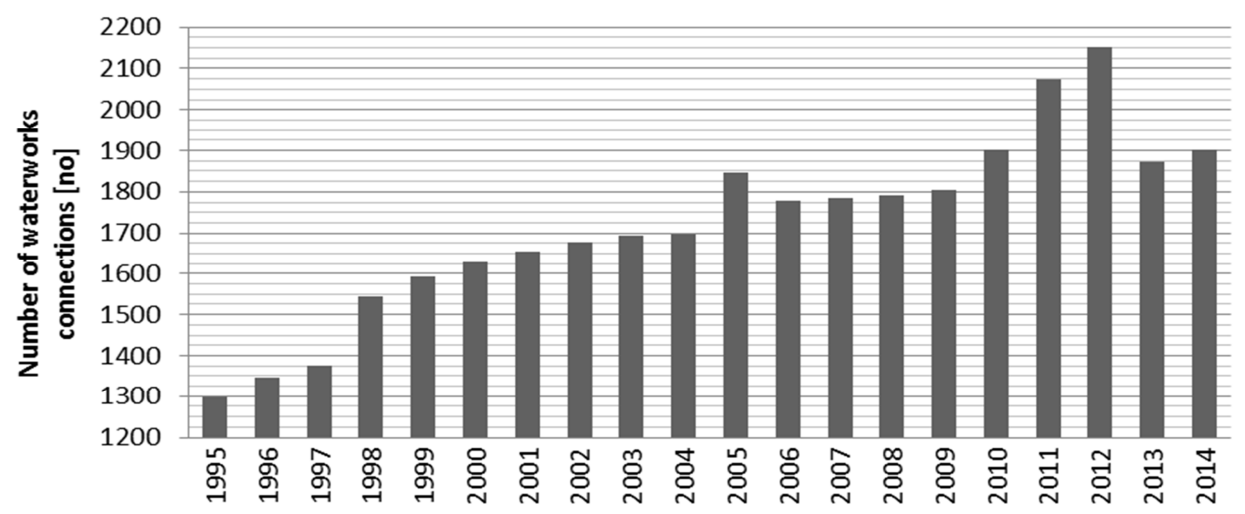

Fig. 5. Number of waterworks connections in Lubaczów

Rys. 5. Liczba przyłączy wodociągowych w miejscowości Lubaczów

The number of water supply connections in Lubaczów in 2014 increased of $46,5 \%$ in comparison to 1995 . The average number of connections was 1,721 , and the relative variation of individual values obtained from the measured average variation coefficient, which reached $13 \%$. The value of the dispersion of results equals 854 water supply connections at the end of 20 years, shows a large increase of water supply connections number in Lubaczów. 
The average value of water supply connections per $1 \mathrm{~km}$ of water supply network for Lubaczów was $65 \mathrm{no} / \mathrm{km}$, while the difference between the maximum and minimum is $21 \mathrm{no} / \mathrm{km}$, which at the end of 20 years shows a slight increase of the number of water supply connections per $1 \mathrm{~km}$ of the length of water supply network in Lubaczów.

In order to assess the development of water supply infrastructure in cities of comparable population the indicators of considered water network in Lubaczów (with a population of 12517) were compared to two selected cities of Podkarpackie Province: Leżajsk (with population 14363) and Nisko (with population 15484). The characteristics was shown in Table 1.

Table 1. The development of water supply infrastructure in cities of comparable population

Tabela 1. Rozwój infrastruktury wodociągowej w miastach o porównywalnej liczbie mieszkańców

\begin{tabular}{|c|c|c|c|c|c|c|c|}
\hline Parametrs & 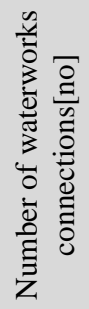 & 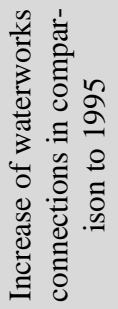 & 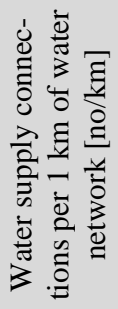 & 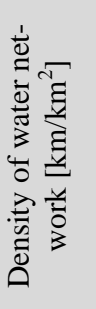 & 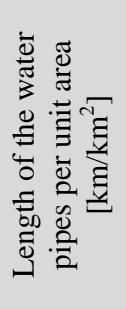 & 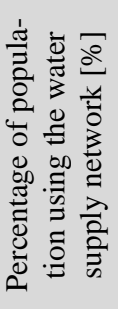 & 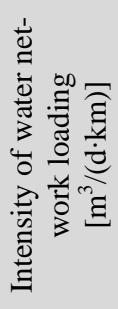 \\
\hline Lubaczów & 1903 & 146,5 & 67 & 1,11 & 1,11 & 96 & 41,3 \\
\hline Leżajsk & 1988 & 165,9 & 20 & 2,64 & 2,64 & 91 & 10 \\
\hline Nisko & 2059 & 2079,8 & 37 & 1,71 & 1,71 & 77,7 & 21,3 \\
\hline
\end{tabular}

The aim of the comparison of Lubaczów with cities of similar population was to assess the impact of each indicator on the water supply infrastructure development. Lubaczów is characterized by small development of water supply infrastructure, while Leżajsk, despite of a similar area and population is characterized by greater expansion of the water supply network. In the years 19952014 the number of population has been changing slightly in Lubaczów, Leżajsk and Nisko. The large discrepancies in the growth of connections, as well as in the length of the water supply network can be seen. Lubaczów is characterized by the lowest increase in the number of connections in the analysed two decades, however, the number of water supply connections per $1 \mathrm{~km}$ of water supply system in comparison with Nisko $(8-30 \mathrm{no} / \mathrm{km})$ and Leżajsk $(36-44 \mathrm{no} / \mathrm{km})$ is the largest and is $57-78 \mathrm{no} / \mathrm{km}$. It indicates small expansion of Lubaczów and dominance of single-family houses. Lubaczów is characterized by the lowest increase of the network length in comparison to the area in the years 1995-2014. In 1995 Leżajsk had the highest rate of network density $1,63 \mathrm{~km} / \mathrm{km}^{2}$ and gradually increased to a value of $2,64 \mathrm{~km} / \mathrm{km}^{2}$ in 2014. Leżajsk and Lubaczów are similar as far as type of building is concerned, but Leżajsk is characterized by greater ex- 
pansion of single-family houses, as well as the length of the water supply network. A small length of water supply network per $1 \mathrm{~km}^{2}$ in Nisko $\left(0,15 \mathrm{~km} / \mathrm{km}^{2}\right)$ in the early years of the analysed two decades and the increase of $1133 \%$ to 2014 indicates that there are more multi-family houses than single-family houses. Such situation allows to observe how significant impact on the water supply infrastructure has a type of buildings in the given city.

One of the most important indicators of the technical condition assessment of the network is the pipe failure rate, which can be presented as the failure rate of the water supply network. It is calculated as the number of failures in pipes that occurred in one $\mathrm{km}$ of pipeline during the relevant time period. This dependence is determined by the formula $[8,9]$ :

$$
\lambda=\mathrm{n} /(\mathrm{L} \cdot \Delta \mathrm{t}),[\text { failure } /(\mathrm{km} \cdot \mathrm{a})]
$$

where:

$\mathrm{n}-\mathrm{a}$ number of failures in the given time interval $\Delta \mathrm{t}$, [failure],

$\mathrm{L}$ - the length of the water supply network in the studied time interval $\Delta \mathrm{t},[\mathrm{km}]$, $\Delta \mathrm{t}$ - considered time interval, [a].

In 2014 the failure rate of distributional pipes was $0,17 \mathrm{failure} /(\mathrm{km} \cdot \mathrm{a})$ and thus it meets the requirements for failure rates of the distributional pipes which equals 0,5 failure/(km·a) $[7,13]$.

In relation to Podkarpackie province Lubaczów has a slightly higher level of failure rate. For cities with a population of 10 000-20 000 the failure rate of distributional pipes is 0,13 failure/(km.a) [13]. Mainly those failures occurred in the winter season and were caused by longitudinal and transverse cracks of pipes.

\section{Conclusion}

The technical condition of the water supply network is not satisfactory, which is the result, among others, of underinvestment in replacing old pipes and years of negligence in maintenance and modernization of the network. More attention is paid to the renovation and construction of new wells, in order to replace depleted wells. It is recommended to renew old water pipes or replace them with the new ones in the future.

In order to minimize costs and improve the water supply system the water company recommended to develop the program of water supply system modernization in the city, as well as the implementation of the project "Improving water supply of Lubaczów inhabitants through the modernization of hydrophone infrastructure in Lubaczów."

Conducting renewal and renovation of water supply system is performed by long-term strategy and its aim is not only to improve water quality but also to reduce the failure rate. 


\section{Literature}

[1] Bergel T., Kaczor G., Bugajski P., Stan techniczny sieci wodociągowych w małych wodociągach województwa małopolskiego i podkarpackiego, Infrastruktura i ekologia terenów wiejskich, $\mathrm{Nr}$ 3/IV/2013, s. 291-304.

[2] Dymaczewski Z., Sozański M.M. Wodociągi i kanalizacja w Polsce tradycja i współczesność, Polska Fundacja Ochrony Zasobów Wodnych, Poznań-Bydgoszcz 2002.

[3] Dziembowski Z., Poradnik wodociągi i kanalizacja. Ekonomika wodociągów i kanalizacji, Część IV, Wyd. Arkady, Warszawa 1971.

[4] Główny Urząd Statystyczny, Ochrona środowiska, Roczniki statystyczne za lata 1995-2014.

[5] Iwanejko R., Leń T.: Analiza uszkadzalności sieci wodociągowej eksploatowanej przez SPGK w Sanoku, Czasopismo Inżynierii Lądowej, Środowiska i Architektury, JCEEA, t. XXXII, z. 62 (1/15), s. 153-166.

[6] Iwanek M., Kowalska B., Kowalski D., Kwietniewski M., Miszta-Kruk K., Mikołajuk P.: Wpływ różnych czynników na awaryjność sieci wodociągowej w układzie przestrzennym - studium przypadku, Czasopismo Inżynierii Lądowej, Środowiska i Architektury, JCEEA, t. XXXII, z. 62 (1/15), s. 167-183.

[7] Kwietniewski M., Rak J.: Niezawodność infrastruktury wodociągowej i kanalizacyjnej w Polsce. Studia z Zakresu Inżynierii, nr 67. Polska Akademia Nauk, Warszawa 2010.

[8] Kwietniewski M., Roman M., Kłoss-Trębaczkiewicz H.: Niezawodność wodociągów i kanalizacji. Arkady, Warszawa 1993.

[9] Mays W. L.: Reliability analysis of water distribution systems. American Society of Civil Engineers, New York 1989.

[10] Pergół S., Sokołowski J., Wody podziemne. Bilans zasobów eksploatacyjnych i dyspozycyjnych wód podziemnych Polski wg stanu na dzień 31.12.2011 r., Państwowy Instytut Geologiczny-Państwowy Instytut Badawczy, Warszawa 2012.

[11] Pietrucha-Urbanik K., Infrastruktura wodociągowa w województwie podkarpackim w latach 1995-2008, Zeszyty Naukowe Politechniki Rzeszowskiej, Budownictwo i Inżynieria Środowiska, Nr 276, z. 58 (2/2011), s. 259-269.

[12] Pietrucha-Urbanik K.: Prioritizing water pipe renewal using fuzzy set theory, Journal of KONBiN 1(33)2015, p. 243-250. DOI 10.1515/jok-2015-032.

[13] Rak J.: Podstawy bezpieczeństwa systemów zaopatrzenia w wodę. Monografie Komitetu Inżynierii Środowiska Polskiej Akademii Nauk, vol. 28. Wydawn. Drukarnia Liber Duo Kolor, Lublin 2005.

[14] Studziński A., Pietrucha-Urbanik K., Mędrala A.: Analiza strat wody oraz awaryjności w wybranych systemach zaopatrzenia w wodę, Czasopismo Inżynierii Lądowej, Środowiska i Architektury, JCEEA, t. XXXI, z. 61 (4/14), 2014, s. 193-201. DOI:10.7862/rb.2014.144.

[15] Wieczysty A.: Metody oceny i podnoszenia niezawodności działania komunalnych systemów zaopatrzenia w wodę. Wydawnictwo Komitetu Inżynierii Środowiska PAN, Kraków 2001. 


\section{ANALIZA STANU INFRASTRUKTURY WODOCIAGOWEJ NA PRZYKLADZIE WYBRANEGO SYSTEMU ZAOPATRZENIA W WODE}

\section{Streszczenie}

W pracy przedstawiono charakterystykę infrastruktury wodociągowej w Lubaczowie. Następnie sporządzono analizę stanu infrastruktury wodociągowej na podstawie zebranych danych eksploatacyjnych. Wyznaczono wskaźniki charakteryzujące infrastrukturę wodociągową w latach 1995-2014. W analizie wykorzystano następujące parametry: długość sieci wodociągowej, liczbę przyłączy wodociągowych, zużycie wody, na podstawie danych uzyskanych z Głównego Urzędu

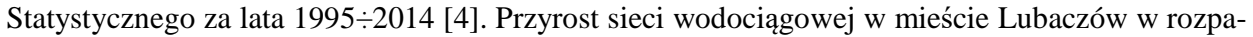
trywanym okresie wyniósł 125,8\%, natomiast średni przyrost długości sieci wodociągowej wyniósł $0,3 \mathrm{~km} / \mathrm{rok}$, na jednego mieszkańca Lubaczowa przypadało 1,87-2,38 m sieci wodociagowej. Wartość intensywności obciążenia sieci wodociągowej w województwie podkarpackim w latach 1995-2009, w przeciwieństwie do Lubaczowa miała tendencję wzrostową. Długość sieci wodociągowej przypadająca na jednostkę powierzchni wynosiła $0,88 \mathrm{~km} / \mathrm{km}^{2}$ w 1995 roku i wzrosła do wartości $1,11 \mathrm{~km} / \mathrm{km}^{2}$ w 2014 roku. Liczba przyłączy wodociągowych prowadzących do budynków mieszkalnych i zbiorowego zamieszkania wzrosła z 1299 szt. w 1995 roku, do wartości 1903 szt. w 2014 roku, więc przyrost wynosi 146,5\%. Średnia liczba przyłączy wodociągowych przypadających na $1 \mathrm{~km}$ sieci wodociagowej w latach 1995-2014 wynosiła 65 szt./km, natomiast różnica pomiędzy wartością maksymalną, a minimalną wynosi $21 \mathrm{szt} . / \mathrm{km}$, co świadczy o niewielkim przyroście tego wskaźnika.

Słowa kluczowe: infrastruktura wodociągowa, wskaźniki rozwoju sieci wodociągowej, wskaźnik intensywności uszkodzeń, sieć wodociągowa

Przestano do redakcji: 29.01.2016 $r$.

Przyjęto do druku: 1.06.2016 r.

DOI: $10.7862 /$ rb.2016.124 